\title{
Perencanaan Sinyal Lalu Lintas Persimpangan Tiga Lengan Pada JL. Imam Bonjol - JL. Abdul Rahman Saleh Kota Pontianak
}

\author{
Heri Azwansyah \\ Kelompok Bidang Keahlian Rekayasa Transportasi \\ Jurusan Teknik Sipil, Fakultas Teknik, Universitas Tanjungpura Pontianak \\ e-mail : heriazwansyah@gmail.com
}

\begin{abstract}
This study aim to plan traffic light at intersection three arm of Imam Bonjol Street - Abdul Rahman Saleh Street in Pontianak City.

This Study require data of intersection geometric and vehicle traffic obtained of field survey.

This study yield planning of traffic light 3 phase with cycle time 160 second. Green time of actual for phase 1 (Street of Jl. Imam Bonjol (a)) equal to 66 second, for phase 2 (Street of Jl. Imam Bonjol (b)) equal to 63 second, and for phase 3 (Street of Abdul Rahman Saleh) equal to 10 second.
\end{abstract}

Keywords- Traffic Light, Cycle Time, Green Time

\section{Pendahuluan}

Sistem jaringan jalan terdiri dari 2 (dua) komponen utama yaitu ruas (link) dan persimpangan (node). Persimpangan merupakan komponen terpenting dalam sistem jaringan jalan karena bagaimanapun baiknya kinerja ruas jalan, jika tidak didukung dengan kinerja persimpangan yang baik maka secara sistem dapat dikatakan kinerja sistem jaringan jalan tersebut dipastikan rendah [8].

Tamin (2008) menyatakan bahwa beberapa penelitian yang dilakukan di beberapa kota besar di Indonesia menyimpulkan bahwa waktu keterlambatan (delay) di persimpangan berkontribusi sebesar hamnpir $60-70 \%$ dari total waktu perjalanan (travel time). Sehingga dapat disimpulkan bahwa penanganan masalah kemacetan di persimpangan merupakan masalah yang sangat krusial dalam usahan mengatasi masalah kemacetan baik dalam sistem jaringan jalan perkotaan maupun antar kota [8].

Persimpangan merupakan suatu ruang/tempat pertemuan antara 2 atau lebih ruas jalan yang bertemu atau bersilangan, bervariasi dari persimpangan yang sangat sederhana yang terdiri dari ruang/tempat pertemuan antara 2 (dua) ruas jalan sampai dengan persimpangan yang sangat kompleks berupa ruang/tempat pertemuan dari beberapa $(>2)$ ruas jalan [8].

Permasalahan pada persimpangan timbul disebabkan oleh pergerakan lalu lintas yang datang dari setiap lengan persimpangan A(belok kiri, lurus, dan belok kanan) semua akan menggunakan ruang/tempat yang sama dan pada waktu yang bersamaan pula sehingga akan menimbulkan titik-titik konflik pada ruang persimpangan tersebut. Hal ini juga terjadai pada simpang tiga lengan Jl. Imam Bonjol - Jl. Abdul Rahman Saleh Kecamatan Pontianak Tenggara Kota Pontianak yang saat ini belum dilengkapi dengan pengaturan lampu lalu lintas.

Saat ini, Jl. Imam Bonjol merupakan jalur utama yang harus dilewati oleh kendaraan berat dan kendaraaan barang ketika melintasi/ meyeberangi sungai kapuas karena hingga saat ini jembatan kapuas I tidak boleh dilewati oleh kendaraan berat dan kendaraan barang. Kendaraan-kendaraan tersebut diarahkan melalui jembatan kapuas II yang berarti alternatif utama akses jalan adalah J1. Imam Bonjol. Kondisi ini membuat J1. Imam Bonjol menjadi meningkat lalu lintasnya karena merupakan salah satu akses utama menuju jembatan kapuas II.

Disamping itu, secara alami pertumbuhan lalu nlintas juga semakin meningkat, hal ini dapat dilihat dari bertumbuhan kendaraan di Kota Pontianak yang terus meningkat. Hal ini semakin membebani jalan-jalan yang ada di Kota Pontianak. Hal ini tentu akan juga membebani Jl. Imam Bonjol dan semakin menambahkan kemacetan pada persimpangan Jl.Imam Bonjol- Jl. Abdul Rahman Saleh. Oleh sebab itu, dilakukan studi perencanaan sinyal lampu lalu lintas persimpangan tiga lengan pada J1.Imam Bonjol- J1. Abdul Rahman Saleh. Tujuan dari kegiatan ini adalah merencanakan sinyal lampu lalu lintas persimpangan tiga lengan pada Jl.Imam Bonjol- Jl. Abdul Rahman Saleh.

\section{Teori Dasar \\ Persimpangan Jalan}

Persimpangan adalah simpul dalam jaringan transportasi dimana dua atau lebih ruas jalan bertemu, disini arus lalu lintas mengalami konflik. Untuk mengendalkan konflik ini ditetapkan aturan lalu lintas untuk menetapkan siapa yang mempunyai hak terlebih dahulu untuk menggunakan persimpangan. Setiap persimpangan mencakup pergerakan lalu lintas menerus dan lalu lintas yang saling memotong pada satu atau lebih dari kaki persimpangan dan mencakup juga pergerakan perputaran. Pergerakan lalu lintas ini 
dikendalikan berbagai cara, bergantung pada jenis persimpangannya [5].

\section{Lalu Lintas}

Lalu lintas (traffic) merupakan kegiatan lalu lalang atau pergerakan kendaraan, orang, atau hewan di jalanan. Masalah yang dihadapi dalam perlalulintasan adalah keseimbangan antara kapasitas jaringan jalan dengan banyaknya kendaraan/orang yang menggunakan jalan. Peningkatan jumlah produksi kendaraan bermotor yang ada tidak sesuai dengan peningkatan fasilitas jalan atau sarana pendukung transportasi yang mana akan berdampak pada kapasitas jalan. Kapasitas jalan yang hampir jenuh atau berlebihan, maka yang mungkin terjadi adalah kemacetan, kecelakaan serta pelanggaran lalu lintas yang makin meningkat $[1,8]$.

Alat Pemberi Isyarat Lalu Lintas adalah perangkat elektronik yang menggunakan isyarat lampu yang dapat dilengkapi dengan isyarat bunyi untuk mengatur Lalu Lintas orang dan/atau Kendaraan di persimpangan atau pada ruas Jalan $[1,4]$.

Alat pemberi isyarat lalu lintas terdiri atas:

a. Lampu tiga warna, untuk mengatur kendaraan;

b. Lampu dua warna, untuk mengatur kendaraan dan/atau Pejalan Kaki; dan

c. Lampu satu warna, untuk memberikan peringatan bahaya kepada Pengguna Jalan.

Alat Pemberi Isyarat Lalu Lintas dengan tiga warna tersusun secara:

a. Vertikal berurutan dari atas ke bawah berupa cahaya berwarna merah, kuning, dan hijau; atau

b. Horizontal berurutan dari sudut pandang Pengguna Jalan dari kanan ke kiri berupa cahaya berwarna merah, kuning, dan hijau.

Alat pemberi isyarat lalu lintas dengan dua warna tersusun secara vertikal dengan:

a. Cahaya berwarna merah di bagian atas; dan

b. Cahaya berwarna hijau di bagian bawah.

Alat Pemberi Isyarat Lalu Lintas dengan satu warna berupa cahaya berwarna kuning kelap kelip atau merah. Lampu tiga warna terdiri atas cahaya berwarna:

a. Merah, dipergunakan untuk menyatakan kendaraan harus berhenti dan tidak boleh melewati marka melintang yang berfungsi sebagai garis henti;

b. Kuning yang menyala sesudah cahaya berwarna hijau padam, dipergunakan untuk menyatakan bahwa cahaya berwarna merah akan segera menyala, kendaraan bersiap untuk berhenti;

c. Kuning yang menyala bersama dengan cahaya berwarna merah, dipergunakan untuk menyatakan bahwa lampu hijau akan segera menyala, kendaraan dapat bersiapsiap untuk bergerak; dan

d. Hijau, dipergunakan untuk menyatakan kendaraan berjalan.

\section{Sinyal Lalu Lintas ( Traffic signal )}

Sinyal lalu lintas adalah suatu alat pengatur lalu lintas yang menggunakan tenaga listrik berfungsi untuk mengontrol arus lalu lintas kendaraan dan pejalan kaki pada persimpangan ataupun tempat lain yang dianggap perlu untuk dipasang [6].
Setiap pemasangan sinyal lalu lintas bertujuan untuk :

1. Menghindari kemacetan simpang akibat adanya konflik arus lalulintas yang berlawanan, sehingga kapasitas persimpangan dapat dipertahankan selama keadaan lalulintas puncak.

2. Menurunkan tingkat frekwensi kecelakaan

3. Mempermudah menyeberangi jalan utama bagi kendaraan dan/ atau pejalan kaki dari jalan minor.

\section{Istilah dalam perencanaan sinyal lampu lalu lintas}

Istilah dalam perencanaan sinyal lampu lalu lintas antara lain $[1,7]$

- Aspek (Aspect)

Yaitu warna sinyal pada lampu lalu lintas dengan urutan Merah-Hijau-Kuning-Merah secara bergantian

Sinyal kuning antara hijau dan merah biasanya 3 detik. Sinyal kuning juga biasa ditempatkan antara sinyal merah dan hijau.

- Fase (Phase)

Yaitu selang waktu dimana sekelompok kendaraan bergerak secara bersama-sama.

Lampu lalu lintas bertujuan agar ruang persimpangan dapat digunakan secara bergantian dengan skenario fase.

- Arus jenuh (Saturation flow)

Yaitu arus keberangkatan maksimum yang dapat dihasilkan dari suatu lengan persimpangan selama selang waktu hijau (smp/waktu hijau) yang merupakan fungsi dari lebar efektif lengan persimpangan.

\section{Waktu Pada Sinyal Lampu Lalu Lintas}

a. Waktu Antar Hijau dan Waktu Hilang

Waktu antar hijau adalah periode kuning dan merah semua antara dua fase yang berurutan, arti dari keduanya sebagai berikut ini [3] :

1) Panjang waktu kuning per fase (WKi) pada sinyal lalu lintas perkotaan di Indonesia adalah 3,0 detik [2].

2) Waktu merah semua pendekat adalah waktu dimana sinyal merah menyala bersamaan dalam semua pendekat yang dilayani oleh dua fase sinyal yang berurutan. Fungsi dari waktu merah semua adalah memberikan kesempatan bagi kendaraan terakhir(melewati garis henti pada akhir sinyal kuning) berangkat sebelum kedatangan kendaraan pertama dari fase berikutnya [2].

Waktu hilang (lost time) adalah jumlah semua periode antar hijau dalam siklus yang lengkap. Waktu hilang dapat diperoleh dari beda antara waktu siklus dengan jumlah waktu hijau dalam semua fase. LTI $=\sum$ (semua merah + kuning)

b. Waktu Siklus dan Waktu Hijau

Waktu siklus adalah urutan lengkap dari indikasi sinyal (antara dua sinyal saat permulaan hijau yang berurutan di dalam pendekat yang sama). Waktu siklus yang paling rendah akan menyebabkan kesulitan bagi pejalan kaki untuk menyebrang, 
sedangkan waktu siklus yang lebih besar menyebabkan memanjangnya antrian kendaraan danbertambahnya tundaan, sehingga akan mengurangi kapasitas keseluruhan simpang [1].

1) Waktu siklus sebelum penyesuaian

$\mathrm{Co}=\frac{(1,5 \times L T+5)}{\left(1-\sum Y i\right)}$

Dengan :

Co = waktu siklus sebelum penyesuaian

$\mathrm{LT}=\mathrm{L} 1+\mathrm{L} 2=$ waktu hilang total per siklus

$\mathrm{Yi}=$ rasio arus simpang fase $\mathrm{i}$

$\Sigma \mathrm{Yi}=$ total rasio arus simpang fase $\mathrm{i}$

2) Waktu hijau efektif (WHEi)

Waktu hijau efektif untuk masing-masing fase :

WHEi $=($ Co - LT $) \times(Y i / \Sigma$ yi $)$

Dengan : WHEi $=$ waktu hijau efektif pada fase $\mathrm{i}$

3) Waktu hijau aktual (WHAi)

Waktu hijau aktual untuk masing-masing fase :

$\mathrm{WHAi}=\mathrm{WHEi}+\mathrm{LT}-\mathrm{WKi}$

Dengan : WKi = waktu kuning pada fase $\mathrm{i}$

\section{Hasil Studi}

\section{Keadaan Lokasi Studi}

Studi ini dilakukan di persimpangan tiga lengan Jl. Imam Bonjol - Jl. Abdul Rahman Saleh, dimana lokasi studi dapat dilihat pada gambar di bawah ini.

Keadaan sekitar lokasi studi adalah Jl. Imam Bonjol memiliki lebar jalan $6 \mathrm{~m} 2$ arah dan merupakan jalan kolektir. Sementara itu, Jl. Abdul Rahman Saleh memiliki lebar jalan $6 \mathrm{~m} 2$ arah dan juga merupakan jalan kolektor. Lingkungan di sekitar lokasi studi berupa daerah pemukiman, perdagangan, dan terdapat perkantoran.

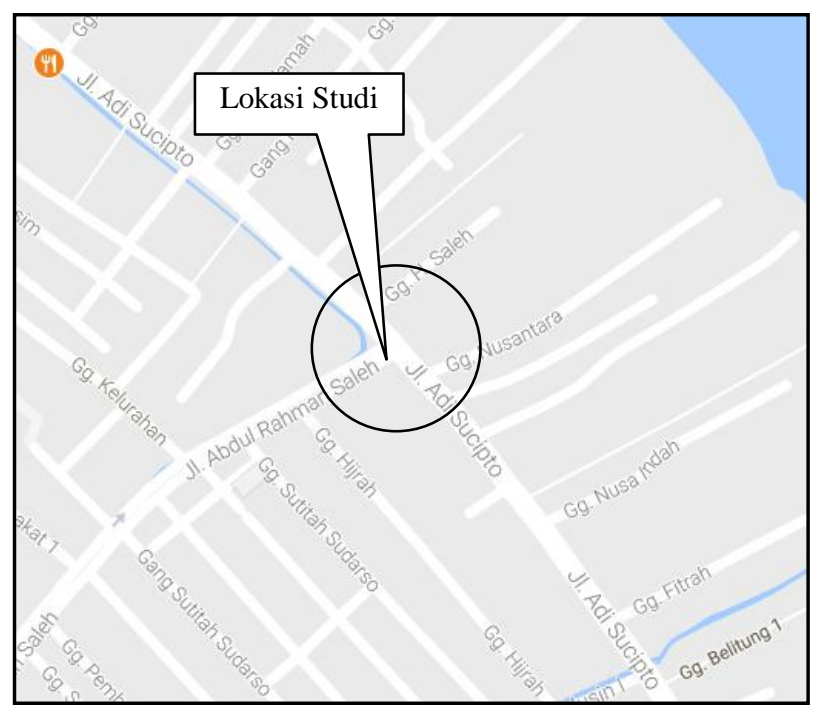

Gambar 1. Lokais Studi.

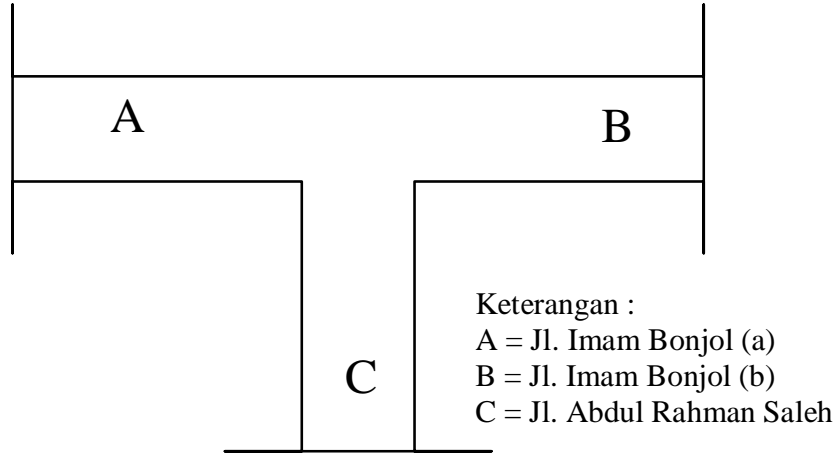

Gambar 2. Sket Persimpangan Imam Bonjol - Abdul Rahman Saleh

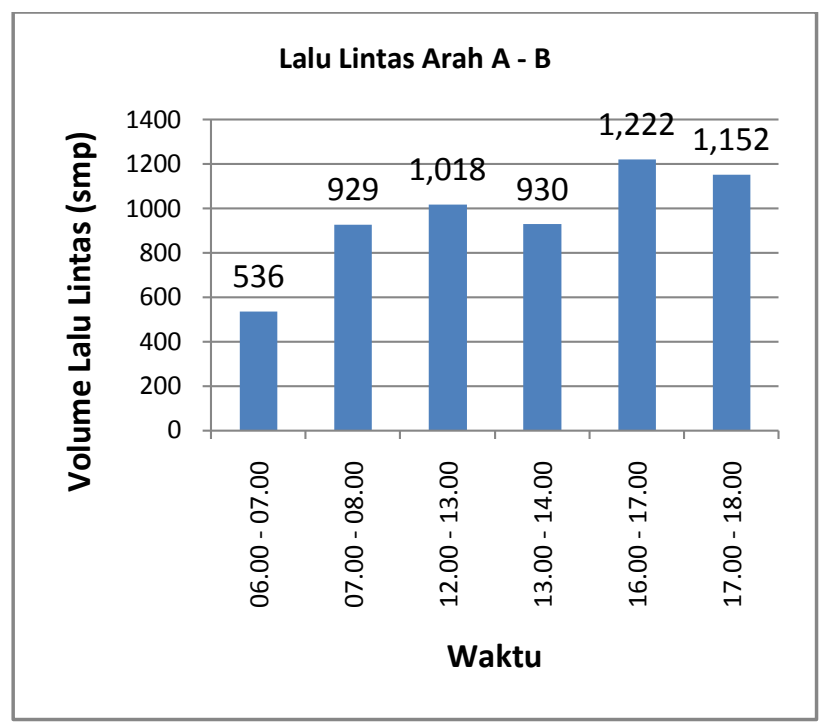

Gambar 3. Karakteristik Lalu Lintas Arah A ke B

Gambar di atas terlihat lalu lintas persimpangan pada jam-jam sibuk pagi, siang dan sore hari yang bergerak dari A ke B, Jl. Imam Bonjol (a) ke Jl. Imam Bonjol (b). Puncak lalu lintas terjadi pada pukul $16.00-17.00$ WIBA sebesar $1.222 \mathrm{smp}$ (satuan mobil penumpang). 


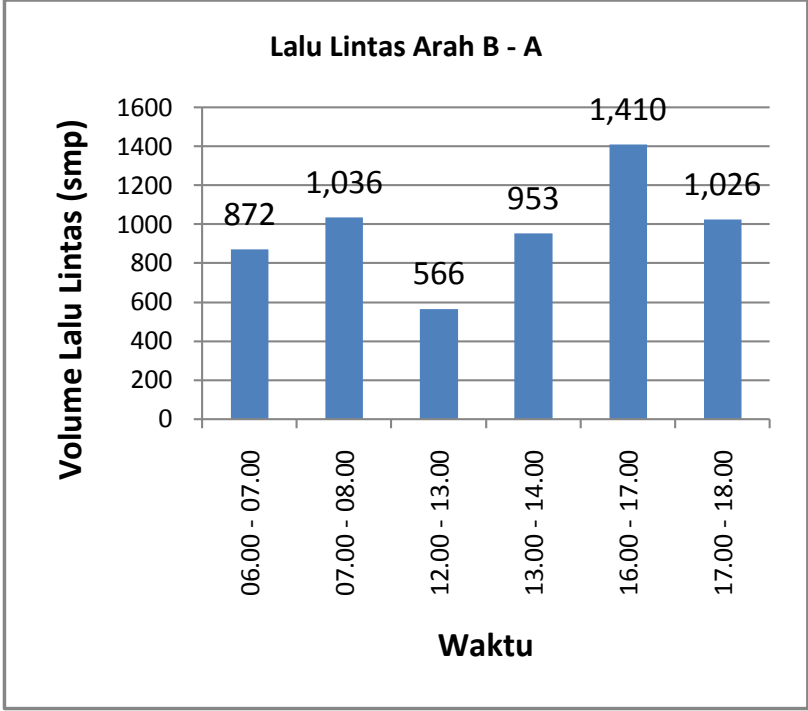

Gambar 4. Karakteristik Lalu Lintas Arah B ke A

Gambar di atas terlihat lalu lintas persimpangan pada jam-jam sibuk pagi, siang dan sore hari yang bergerak dari B ke A, Jl. Imam Bonjol (b) ke Jl. Imam Bonjol (a). Puncak lalu lintas terjadi pada pukul 16..00 - 17.00 WIBA sebesar $1.410 \mathrm{smp}$.

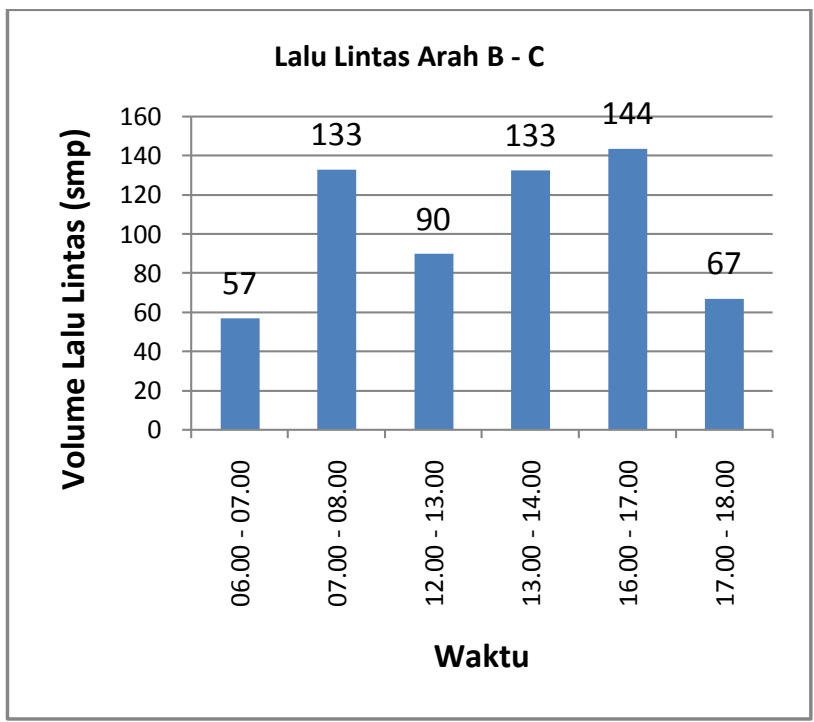

Gambar 5. Karakteristik Lalu Lintas Arah B ke C

Gambar di atas terlihat lalu lintas persimpangan pada jam-jam sibuk pagi, siang dan sore hari yang bergerak dari B ke C, Jl. Imam Bonjol (b) ke Jl. Abdul Rahman Saleh. Puncak lalu lintas terjadi pada pukul 16.00 17.00 WIBA sebesar 144 smp.

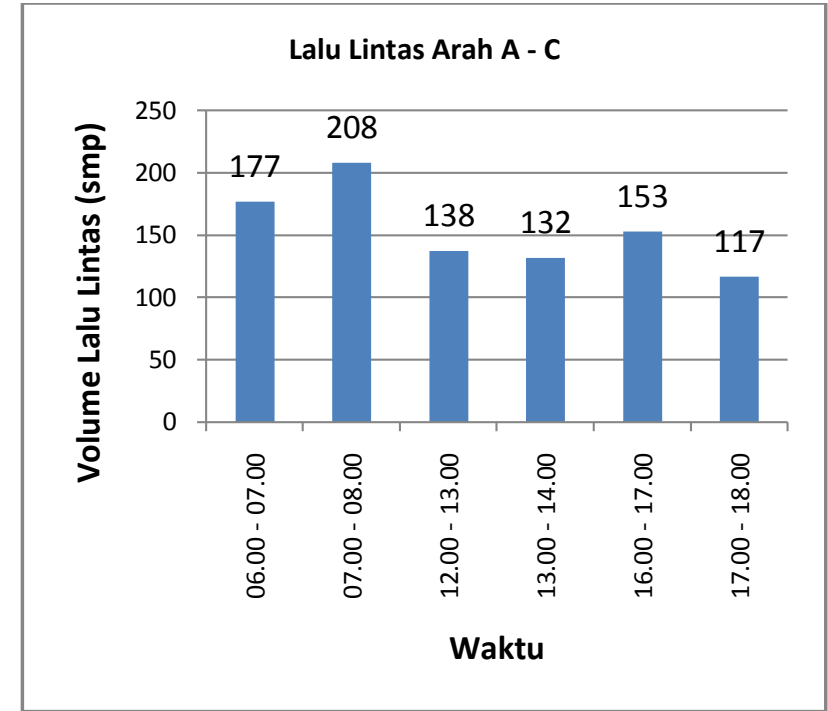

Gambar 7. Karakteristik Lalu Lintas Arah A ke C

Gambar di atas terlihat lalu lintas persimpangan pada jam-jam sibuk pagi, siang dan sore hari yang bergerak dari A ke C, Jl. Imam Bonjol (a) ke Jl. Abdul Rahman Saleh. Puncak lalu lintas terjadi pada pukul 07.00 08.00 WIBA sebesar $208 \mathrm{smp}$.

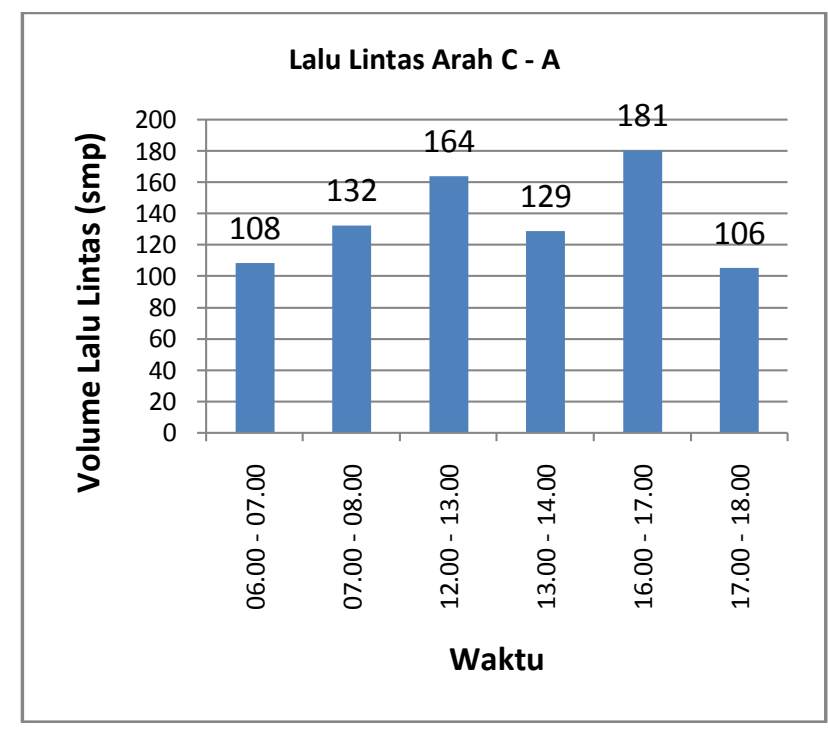

Gambar 8. Karakteristik Lalu Lintas Arah C ke A

Gambar di atas terlihat lalu lintas persimpangan pada jam-jam sibuk pagi, siang dan sore hari yang bergerak dari C ke A, ke Jl. Abdul Rahman Saleh ke Jl. Imam Bonjol (a). Puncak lalu lintas terjadi pada pukul 16.00 17.00 WIBA sebesar $181 \mathrm{smp}$.

\section{Perhitungan Lampu Lalu Lintas}

Berdasarkan data tertsebut diperolah informasi lalu lintas setiap lengan persimpanagan sebagai berikut : 
Tabel 1. Data Parameter Lalu Lintas dan Geometrik Simpang

\begin{tabular}{cccc}
\hline \multirow{2}{*}{ Parameter } & \multicolumn{3}{c}{ Lengan Persimpangan } \\
\cline { 2 - 4 } & $\mathrm{A}$ & $\mathrm{B}$ & $\mathrm{C}$ \\
\hline $\mathrm{W}(\mathrm{m})$ & 6 & 6 & 10 \\
\hline $\mathrm{q}(\mathrm{smp} / \mathrm{j})$ & 1.117 & 1.078 & 247 \\
\hline $\mathrm{s}(\mathrm{smp} / \mathrm{j})$ & 3.150 & 3.150 & 5.250 \\
\hline
\end{tabular}

Sumber : Pengolahan Data, 2015

Dalam studi ini akan direncanakan pengaturan sinyal lampu lalu lintas dengan 3 fase dengan penjelasan sebagai berikut :

Selang waktu antar hijau (WAH) $=7$ detik dan waktu kuning $(\mathrm{WK})=3$ detik, sehingga watu merah semua $(\mathrm{WMS})=\mathrm{WAH}-\mathrm{WK}=7-3=4$ detik, serta total waktu kehilangan pada saat selang waktu hijau (L1 + L2) $=4$ detik.

Tabel 2. Analisis Nisbah Arus Lalu Lintas Dengan Arus Jenuh Untuk Pengaturan Sinyal 3 fase

\begin{tabular}{cccc}
\hline \multirow{2}{*}{ Parameter } & \multicolumn{3}{c}{ Lengan Persimpangan } \\
\cline { 2 - 4 } & $\mathrm{A}$ & $\mathrm{B}$ & $\mathrm{C}$ \\
\hline $\mathrm{q}(\mathrm{smp} / \mathrm{j})$ & 1.117 & 1.078 & 247 \\
\hline $\mathrm{s}(\mathrm{smp} / \mathrm{j})$ & 3.150 & 3.150 & 5.250 \\
\hline $\mathrm{Y}=\mathrm{q} / \mathrm{s}$ & 0,3545 & 0,3422 & 0,0497 \\
\hline $\mathrm{Yi}$ & 0,3545 & 0,3422 & 0,0497 \\
\hline$\Sigma \mathrm{Yi}$ & & 0,7437 & \\
\hline
\end{tabular}

Sumber : Hasil Analisis, 2015

Total waktu kehilangan (L) adalah :

$\mathrm{L}=\mathrm{N}(\mathrm{WMS}+\mathrm{L} 1+\mathrm{L} 2)=3(4+4)=24$ detik

Waktu siklus optimum (Co) adalah :

$\mathrm{Co}=(1,5 \mathrm{~L}+5) /(1-\Sigma \mathrm{Yi})=((1,5 \times 24)+5) /(1-0,7437)$

$=160$ detik

Sehingga, total waktu hijau efektif (WHE) adalah :

$\mathrm{WHE}=\mathrm{Co}-\mathrm{L}=160-24=136$ detik

Waktu hijau efektif setiap fase (WHEi) dapat dihitung sebagai berikut :

Fase $1(\mathrm{~A})$ : WHE1 $=(\mathrm{Y} 1 / \Sigma \mathrm{Yi}) \mathrm{x}$ WHE

$$
\begin{aligned}
& =(0,3545 / 0,7437) \times 136 \\
& =65 \text { detik }
\end{aligned}
$$

Fase $2(\mathrm{~B}):$ WHE2 $=(\mathrm{Y} 2 / \Sigma \mathrm{Yi}) \times \mathrm{WHE}$

$$
\begin{aligned}
& =(0,3422 / 0,7437) \times 136 \\
& =62 \text { detik }
\end{aligned}
$$

Fase $3(\mathrm{C}):$ WHE3 $=(\mathrm{Y} 3 / \Sigma \mathrm{Yi}) \times \mathrm{WHE}$

$$
\begin{aligned}
& =(0,0470 / 0,7437) \times 136 \\
& =9 \text { detik }
\end{aligned}
$$

Waktu hijau aktual setiap fase (WHAi) dapat dihitung sebagai berikut :

$$
\begin{aligned}
& \text { Fase } 1 \text { (A) : HWA1 = WHE1 + L1 + L2 - WK1 } \\
& =65+4-3=66 \text { detik } \\
& \text { Fase } 2 \text { (B) : HWA2 }=\text { WHE2 + L1 + L2 }- \text { WK2 } \\
& =62+4-3=63 \text { detik } \\
& \text { Fase } 3 \text { (C) : HWA3 }=\text { WHE3 + L1 + L2 }- \text { WK3 } \\
& =9+4-3=10 \operatorname{detik}
\end{aligned}
$$

Digaram waktu yang dihasilkan adalah sebagai berikut :

$\mathrm{Co}=160$ detik

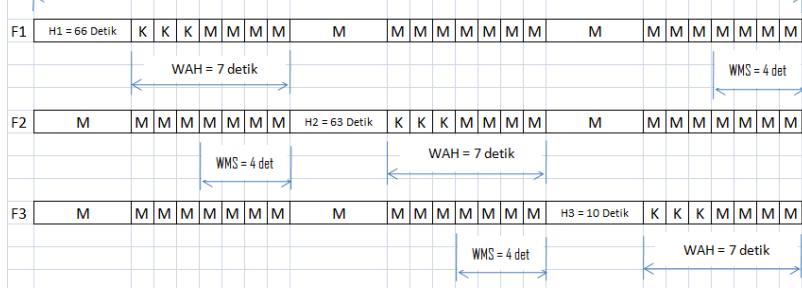

Gambar 1. Diagram Waktu Sinyal Lampu Lalu Lintas

\section{Kesimpulan}

Adapun beberapa hal yang dapat disimpulkan dari studi ini adalah sebagai beikut:

1. Lebar jalan yang ada pada simpang Jl. Imam Bonjol - Jl. Abdul Rahman Saleh relatif cukup dalam mengalirkan lalu lintas yang ada.

2. Hasil perancangan dengan 3 fase, dimana fase 1 adalah pergerakan dari Jl. Imam Bonjol (a), fase 2 pergerakan dari Jl. Imam Bonjol (b), dan fase 3 pergerakan dari Jl. Abdul Rahman Saleh, dalam hal ini diperoleh waktu siklus optimum selama 160 detik, waktu antar hijau tiap fase selama 7 detik, waktu merah semua selama 4 detik, waktu hijau aktual fase 1 selama 66 detik, waktu hijau aktual fase 2 selama 63 detik, dan waktu hijau aktual fase 3 selama 10 detik. 


\section{Referensi}

[1] Azwansyah, H., Juniardi, F., Perencanaan Sinyal Lampu Persimpangan Tiga Lengan Pada Jl. Imam Bonjol- Jl. Abdul Rahman Saleh Kota Pontianak, Jurnal Elkha, Maret, Pontianak, 2015

[2] Dirjen Bina Marga, Manual Kapasitas Jalan Indonesia, Jakarta, 1997.

[3] Ikhwan, M., Legowo, S.J., Amiratul MHM, Analisis dan Simpang Sumber dan Simpang POM Bensin Manahan, $\boldsymbol{e}$ Jurnal MATRIKS TEKSIK SIPIL, September, Surakarta, 2014.

[4] Permen RI No. 79 Tahun 2013 tentang Jaringan Lalu Lintas dan Angkutan Jalan, Jakarta, 2013.

[5] Royan, N., Analisis Pererncanaan Traffic Light di Persimpangan Bandara SMB II Palembang, Jurnal Berkala Teknik, September, Palembang, 2015.

[6] Syahabudin, F.,I., Perencanaan Lampu Pengatur Lalu Lintas Pada Persimpangan Jalan Sultan Hasanudin dan Jalan Ari Lasut Menggunakan Metode MKJI, Jurnal Sipil Statik, Oktober, Makasar, 2015.

[7] Tamin, OZ, Perencanaan, Pemodelan dan Rekayasa Transportasi, Penerbit ITB, Bandung, 2008

[8] Warpani, S., Pengelolaan Lalu Lintas dan Angkutan Jalan, Penerbit ITB, Bandung, 2002

\section{Biografi}

Heri Azwansyah, dilahirkan di Pontianak, Indonesia, pada tanggal 30 Nopember 1973. Ia menyelesaikan program sarjana teknik sipil (S1) pada tahun 1999 di Fakultas Teknik Universitas Tanjungpura, Pontianak, Indonesia, dan menyelesaikan program magister teknik (S2) pada tahun 2002 di Institut Teknologi Bandung, Bandung, Indonesia. Sejak tahun 2000 sebagai peserta pendidikan magister ikatan dinas, ia diangkat sebagai staf pengajar pada Fakultas Teknik Univeristas Tanjungpura, Pontianak, Indonesia. Penelitian sekarang menekuni masalah perencanaan dan pemodelan transportasi, rekayasa lalu lintas, pengembangan sistem informasi transportasi, dan aksesibilitas infrastruktur. 